\section{THE LONDON CONFERENCE ON OPTICAL INSTRUMENTS}

$\mathrm{T}$

HE London Conference on Optical Instruments, held at the Imperial College of Science and Technology during July 19-26, was timed to follow the meetings of the International Optical Commission, and was attended by nearly all the delegates of the latter. This helped to give a genuinely international flavour to a very successful series of meetings.

The declared object of the Conference was "to obtain a survey of modern practice and trends in the construction of actual instruments"; but the proceedings also included symposia on the diffraction theory of optical instruments and on phase-contrast microscopy, and from the scientific point of view these were the most interesting sessions. Also noteworthy were the papers and discussions on reflecting microscopes ; here the interest was mainly technological.

After the opening address by Sir Thomas Merton, president of the Conference, an account was given by Prof. S. S. Ballard of recent optical developments in the United States. Next, M. A. Maréchal (Paris) spoke about recent French researches on diffraction in optical instruments and showed interesting slides of particular cases of diffraction patterns, calculated on his integrating machine in the Iristitut d'Optique, associated with aberrations amounting to several wave-lengths, that is, of amounts not at present easy to deal with by more analytical methods.

Dr. H. H. Hopkins described some investigations of his own into partial coherence and its connexion with microscopic resolution. Mr. Barham gave an accourit of his joint paper with Dr. Hopkins entitled "The Influence of Condenser Aperture on Microscopic Resolution".

Dr. E. Wolf then spoke about his recent work on the three-dimensional distribution of light in diffraction images near focus ; this work has some important applications to the theory of telescopic star images. Dr. E. H. Linfoot described in outline how diffraction theory could be applied to discuss the systematic errors inherent in phase contrast testing with a slit. source; his main result was that these errors do not impair the usefulness of the test for ordinary purposes.

The second day, July 20, was devoted to purely technical accounts of certain newly designed lenses for photography and for television. Mr. R. Kingslake (Eastman Kodak) described some recent developments of photographic objectives in the United 'States. Dr. Hopkins spoke about the 'zoom' lenses on which he has been working recently, and Mr. Warmisham (of Taylor, Taylor and Hobson, Ltd.) described a new $f / 1$ objective with an $18^{\circ}$ spherical field, intended primarily for radiology. A reception at the Royal Institution, followed by a discourse on phosphorescence by Prof. E. N. da C. Andrade, concluded the day.

July, 21 was occupied by visits to the Nationa] Physical Laboratory and to other centres of optical activity.

On July 24 the proceedings began with a general survey by Dr. R. Barer, entitled "Practical Requirements in a Reflecting Microscope". Dr. A. Bouwers (Delft) followed with an account of the concentric mirror microscopes recently put on the market by his firm. Finally, Mr. D. S. Grey (Polaroid Corporation, U.S.A.) spoke on catadioptric microscopes.

In the afternoon, Prof. Curtis, Dr. G. R. Harrison and Mr. C. L. Bausch (Massachusetts Institute of
Technology), Dr. E. Ingelstam and Dr. E. Hulthén (Sweden), and Mr. E. Lind (University of Stockholm) read papers on various aspects of grating spectroscopy.

July 25 was mainly devoted to phase contrast microscopy. Papers were given by Prof. F. Scandone (Italy), Mr. F. W. Cuckow, and Dr. M. Françon (France), the last of whom described with rapidly and beautifully executed blackboard drawings his interesting devices for adapting standard microscopes to phase contrast work by the addition of an auxiliary optical system in front of the objective. Mr. E. Bergstrand (Sweden) discussed work on the velocity of light and the measurement of distances by a development of the Kerr cell method which uses crystal-controlled high-frequency fields. Mr. J. Guild (National Physical Laboratory) spoke on photometry. In the evening a large gathering at the Royal Astronomical Society's rooms in Burlington House received with enthusiasm a talk by Dr. M. A. Ellison on "New Tools for Solar Physics", which included a showing of Menzel's exciting film, "Explosions in the Sun". A parallel gathering in the Royal Photographic Society's rooms heard Mr. R. McV. Weston on the filming of living tissues with the microseope.

The morning of the concluding day, July 26, was occupied by three papers on spectrophotometry, the speakers being Prof. S. S. Ballard (United States), Dr. F. Devignes (France), and Dr. H. W. Thompson (Oxford). In the afternoon, talks on "The Moderm Reflecting Telescope" and on a lens-mirror system for high-precision theodolites were given by Dr. E. H. Linfoot and by Dr. W. Lotmar (Switzerland), respectively ; the Astronomer Royal was in the chair.

Most of the papers were followed by well-informed discussions, and a tendency to refrain from mutual criticism, noticeable at the early meotings, was corrected later on at the urgent request of the Conference's efficient secretary, Prof. L. C. Martin.

\section{E. H. LINFooT}

\section{INDUSTRY AND THE UNIVERSITIES IN GREAT BRITAIN}

THE report of the Conference on Industry and the Universities, organised by the Education and Industrial Research Committees of the Federation of British Industries last November* and at which both industry and all the universities of Great Britain were represented, as well as the British Institute of Management and the Administrative Staff College, has now been published; it includes an analysis of the forty-three replies received to a twelve-point questionnaire previously sent out to individual industrialists regarding their experience in employing university graduates or reasons for being unable to make use of them. These replies, which covered positions in industry for which graduates are recruited, opportunities and prospects, periods of training after recruitment, qualities and characteristics sought by industry in its graduate recruits and comments on the current standard of graduates and the success of the universities in educating men for industry, were summarized and circulated to those attending the Conference and provided a basis for discussion.

Sir Hubert Henderson, opening the discussion on behalf of the universities, commented that the general

* Report of the Conference on Industry and the Universities, organised by the FBI Education and Industrial Research Committees and held at Ashorne Hill, Leamington Spa, 25 to 28 November 1949. Pp. 94. (London: Federation of British Industries, 1950.) 38 . 
tone of the replies showed that there is already a much greater appreciation of the point of view of the universities than might have been found a short time ago. $\mathrm{He}$ endorsed Sir Charles Tennyson's observation that the prime function of the universities is to maintain and advance the standards of knowledge, and said that scholarship and research must be their dominant objectives: even the essential function of teaching would suffer if there were an attempt to subordinate the primary functions of maintaining and advancing the standard of knowledge to what was intended to be more efficient teaching. Sir Hubert thought, too, that the distinction between fundamental and applied knowledge can be overstressed; he knew of nothing more important in the history of the development of human thought than the advances which have been made by a constant interplay between abstract analysis and the attempts to solve particular concrete problems. Nevertheless, he agreed that things that are in the nature of techniques cannot profitably be taught in a university.

The report of the Conference includes brief summary reports from the discussion groups, which considered postgraduate studies and research, education for management, the supply of science teachers for schools, the interpretation of industry within the universities, and the development of closer relationships between industry and the universities. There was also some general discussion on the first three of these subjects, and the general feeling of the Conference was in favour of the Federation of British Industries doing what it can to see that the seriousness of the position regarding science masters is fully realized by the proper authorities. There was a decided cleavage of opinion as to whether management studies are appropriate for a university, most industrialists remaining neutral ; but the Conference was agreed as to the desirability of not labelling courses so as to suggest that they represent the one and only approach to management.

At the third session, which considered industry's requirements of scientific workers and technologists and their education and training, Sir Arthur Fleming said that he preferred to absorb the graduate when he had gained his first degree ; but urged the import. ance of giving the graduate the greatest possible amount of responsibility when he enters industry. Sir Arthur advocated at least two years training in works departments for the technologist. WingCommander T. R. Cave-Browne-Cave stressed the importance of personal qualities and of realistic personal touch between industry and universities. Prof. P. M. S. Blackett doubted the value of management courses and of vacation work ; vacations offer invaluable opportunities of building character in other ways, and he pointed out that the universities can claim that, whether or not they produce the best men, a large and increasing proportion of the best of the youth of the country goes to the university and, when there, wishes to study a large variety of subjects.

Lord Simon of Wythenshawe presided over the fourth session, which dealt with industry's requirements of arts graduates, and the discussion was opened by Sir Humphrey Gale, who put, first, character, personality and power of leadership and, next, ability to write and speak clearly and to express succinctly the essentials of any given situation. Selection of arts graduates by industry requires more exacting methods than the selection of technologists, and he thought that appropriate use of such graduates might relieve technologists of marginal administrative work and reduce requirements of technologists. Lord Eustace Percy stressed the importance of the problem and the need not only to experiment with selection methods but also for the universities themselves to experiment both with different methods of teaching in the older established arts courses and with newer arts courses. Miss Marjorie Hayward said that she was encouraged by the importance attached to personal qualities but referred to the difficulties of placing arts graduates in industry. It was clear that this problem caused some concern to the Conference, and that it would be difficult to place the increased number of arts graduates of average ability unless industry could arrange training and apprenticeship schemes for them.

At the fifth session, Dr. Percy Dunsheath, Mr. C. Morris and Dr. A. E. Trueman attempted to summarize the preceding discussions and conclusions. The first two appealed for the fullest possible understanding between industry and the universities on all the important matters raised, and Dr. Trueman referred to the investigations into the supply and demand of scientific workers and technologists being undertaken by the Hankey Committee for the Ministry of Labour and the necessity of avoiding any steps likely to produce heavy graduate unemployment or misemployment. He urged that the universities should not be pressed to expand further, until they have had time to provide accommodation for the present increased numbers.

Particular points calling for action, which emerged at the Conference, were that a much greater supply of information by industry on its structure and its requirements of graduates should be made available to the universities and schools, and that industrialists should be encouraged to take a greater interest in the universities through their governing bodies, advisory councils and appointments boards, and, conversely, that university staffs should become better acquainted with industry. In regard to the first, information. about careers in the various branches of industry and in individual firms is needed, and it was suggested that the Federation of British Industries could help by supplying such information. The interpretation of industry to the universities could be improved by temporary exchanges of industrial and university research staffs on an individual basis, and industry might further help by arranging short refresher and background courses for university professors and lecturers. The value of vacation courses was fully recognized, for arts students as well as for scientific workers and technologists, but not to the exclusion of other vacation activities. Increased flexibility in the postgraduate courses offered by the universities was suggested; and it was also proposed that the Federation of British Industries, in conjunction with the University Grants Committee, should organise a small team under the auspices of the Anglo-American Productivity Council to visit the United States for studying the relationship between American universities and industry, in order to see whether, and, if so, to what extent, this relationship is connected with the high productivity of American industry. Although the Conference considered that the shortage of science graduates would persist for several years, whether the position would thereafter improve remains uncertain, and industry should examine further the possibility of effecting economies in its use of science graduates. 